\title{
Effect of one cycle of heating-cooling on the clay-concrete pile interface behavior
}

\author{
Abedalqader Idries ${ }^{1}$, Ismaail Ghaaowd ${ }^{2}$, and Murad Abu-Farsakh ${ }^{3 *}$ \\ ${ }^{1}$ Research Assistant, Depart. of Civil \& environmental Engineering, Louisiana State University, Baton Rouge, LA 70808, USA \\ ${ }^{2}$ Research Associate IV, Louisiana Transportation Research Center, Louisiana State University, Baton Rouge, LA 70808, USA \\ ${ }^{3}$ Research Professor, Louisiana Transportation Research Center, Louisiana State University, Baton Rouge, LA 70808, USA
}

\begin{abstract}
This study investigated the effect of applying one heating-cooling cycle on the interface strength parameters of saturated clay soil-concrete, and the potential use of the heating process to improve the side capacity of piles driven in clayey soil. A large direct shear test device with inner dimensions of $300 \mathrm{~mm}, 300$ $\mathrm{mm}$, and $200 \mathrm{~mm}$ for width, length, and height, respectively was modified to perform the interface soilconcrete tests. A concrete block $(300 \mathrm{~mm} \times 300 \mathrm{~mm} \times 100 \mathrm{~mm})$ was built and placed at the bottom section of the shear device. Watlaw heating fire rods system was used to heat the circulating water that heat the specimens. The experimental tests were conducted on Low Plasticity Index soil with PI=12. The specimens were first consolidated to a target normal stress prior to shearing. Two specimens at different testing temperature (room temperature $=20^{\circ} \mathrm{C}, 70^{\circ} \mathrm{C}$ ) were tested for each of the four different normal stresses $(30$, 69,110 , and $150 \mathrm{kPa}$ ). The temperature for the heated specimens was increased gradually during the heating process from the room temperature $\left(20^{\circ} \mathrm{C} \pm 2{ }^{\circ} \mathrm{C}\right)$ to $70^{\circ} \mathrm{C} \pm 2{ }^{\circ} \mathrm{C}$ in 3 hours. The specimens were then cooled back to room temperature. The test results showed significant increase in both peak and residual interface shear strength parameters by $13.6 \%$ and $15.6 \%$ increase in friction angle, respectively. Also, volumetric strain under shearing decreased after the heating and cooling cycle by $30.0 \%, 24.4 \%, 11.3 \%$, and $24.2 \%$ under 30 $\mathrm{kPa}, 69 \mathrm{kPa}, 110 \mathrm{kPa}$, and $150 \mathrm{kPa}$, respectively.
\end{abstract}

\section{Introduction}

Many experiments were performed to study the effect of heat variation on clay's properties. Most of the conducted tests showed that the normally consolidated clay soil (NC) subjected to heating experienced contraction [10, 14]; while a slightly over-consolidated (OC) clay showed initial dilation followed by contraction under heating and contraction under cooling $[10,14]$. However, highly OC material experienced an expansion during heating [10, 14]. For both NC and slightly OC clay, the material shows irrevocable deformation under thermal loading at constant mechanical load $[9,10,14]$.

Under cooling following heating, some researchers observed an irrecoverable contraction for NC clay $[1,3$, 17]; while others observed partial expansion recovery [9]. However, a recoverable deformation was noticed for a highly OC material (i.e., OC more than 1.5 to 3 ) $[5,13$, 16]. In some cases, researchers observed a decrease in the apparent preconsolidation pressure with increasing temperature at constant void ratio and applied mechanical load $[2-4,6,8,10,14]$. In contrast, the applied mechanical load or the maximum historical load is constant.

Di Donna [9] found no effect of heating on the interface friction angle between the concrete and sand. The effect of heating on pullout capacity of pile embedded in sand was investigated by Elzeiny et al. [11], in which the pile capacity was increased after heating and cooling cycle as compare to pile pullout capacity at the room temperature. The effect of temperature on the saturated clay-concrete interface was studied by Di Donna [9]. The tests were performed at room temperature and at an elevated temperature of $50^{\circ} \mathrm{C}$. The clay soil experienced volumetric contraction during the shearing and an increase in shear strength. Yavari et al. [19] found negligible effect of temperature on clay-concrete shear strength conducted at temperatures between $5{ }^{\circ} \mathrm{C}$ and 40 ${ }^{\circ} \mathrm{C}$. Yazdani et al. [20] found that the peak shear stress under heat-cool cycles was increased by $5 \%$; while the strain at the peak stress was slightly decreased. They also found an increase in interface friction angle by $27 \%$ and $25 \%$ for the cyclic and monotonic heating, and $17 \%$ to $20 \%$ reduction in adhesion with temperature from $24{ }^{\circ} \mathrm{C}$ to $34{ }^{\circ} \mathrm{C}$. Xiao et al. [18] found that the ultimate shear strength of the silt at $38^{\circ} \mathrm{C}$ was $15.21 \%$ higher than that at $4{ }^{\circ} \mathrm{C}$. In addition, the angle of friction at $21{ }^{\circ} \mathrm{C}$ was higher than that at $6{ }^{\circ} \mathrm{C}$, but with less cohesion than that at $6{ }^{\circ} \mathrm{C}$. The ultimate shear strength at the soil-concrete interface at $21^{\circ} \mathrm{C}$ was found to be $5 \%$ to $16 \%$ higher than that at $6{ }^{\circ} \mathrm{C}$.

\section{Testing setup}

The large direct shear device (LDSD) available at Louisiana Transportation Research Centre was modified and used in the testing, as shown in Figure 1. In this research it was chosen to investigate the effect of heatingcooling of one cycle on the shear strength parameters of

* Corresponding author: cefars@1su.edu 
clay-concrete interface as it is believed to reflect better and more clear results than of a small direct shear device. This device can endure temperatures up to $80{ }^{\circ} \mathrm{C}$. The highest temperature was applied in this research was chosen to be 70 . The device consists of two sections, the upper section is stationary with dimension of $(300 \mathrm{~mm} \times$ $300 \mathrm{~mm} \times 100 \mathrm{~mm}$ ), and the bottom section with dimension of $(400 \mathrm{~mm} \times 300 \mathrm{~mm} \times 100 \mathrm{~mm})$, and can be moved horizontally during loading. Water level was set $50 \mathrm{~mm}$ below the top of the upper section. Top plate was designed to be stiff enough to transfer the stresses into the top of the soil specimen. The normal stress was applied on the top plate via a stepper motor, and the shear stress was applied by moving the bottom section via horizontal motor at certain shearing rate. Both the top and bottom motors were controlled automatically by the control panel. One side of the upper box was replaced by another one that was manufactured to include three grooves to provide space for the wires of thermocouples. Two grooves were made at the two ends and one at the centre. The grooves start from $6 \mathrm{~mm}$ from the bottom up to the end top. A concrete block with similar roughness to concrete pile surface used by the construction companies in Louisiana was prepared, cured, and placed inside the lower box. To enhance the device ability of testing fine soil such as clay, $25 \mathrm{~mm}$ thick porous stone was prepared by mixing, by weight, $95 \%$ of coarse sand that is passing sieve \# 10 and retained on sieve \# 30 and $5 \%$ of epoxy [12]. Stainless steel reinforcement was placed at the middle of the porous stone to improve its ability for resisting any tension stresses during sample preparation, testing, or storing. Four T-nut female thread were placed at the corners of the porous stone to help in lifting the porous stone. The clayey soil was placed in the upper box up to $50 \mathrm{~mm}$ thickness.

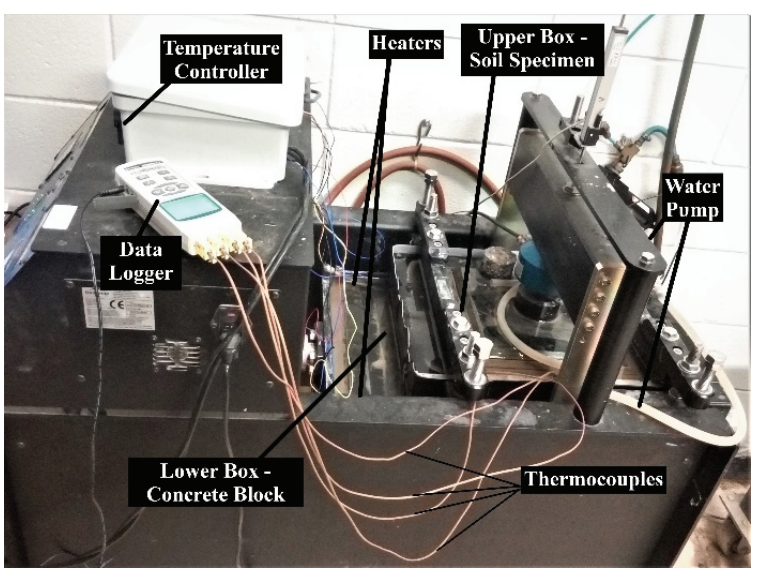

Fig. 1. LDSD used to perform tests at LTRC.

Two Watlow Cartridge Heaters were submerged in the water path and controlled by Watlow controller to heat the circulating water to the target temperature. Each heater was connected to Watlow controller in order to control the temperatures by a k-type thermocouple inserted in the water bath adjacent to the heater. Another four k-type thermocouples were installed to measure soil temperature, one inside the water path and three were inserted inside the clay specimen. The location of the three thermocouples inside the soil specimen was chose to reflect best readings of temperatures. They were inserted inside the clay specimen at $6 \mathrm{~mm}$ above the concrete surface at the centre, at the corner, and at the middle of one side. Omega data logger was used to record the temperature during the testing stages in a one-minute step both during heating and cooling. Finally, water pump was used to circulate the water from the water path to the top of the cap above the shear box to ensure uniform temperature in the whole system, accelerate the heating process, and ensure saturation.

\section{Material properties}

Three clay soils with different plasticity were considered in this study, including high plasticity clay $(\mathrm{PI}=55)$, medium plasticity clay $(\mathrm{PI}=30)$, and low plasticity clay $(\mathrm{PI}=12)$ (i.e. lean clay). Also, cyclic loading was performed on the lean clay alone. However, only the results of tests performed on lean clay under one heatingcooling cycle is presented in this paper due to limited space. The geotechnical properties of the lean clay are liquid limit $=33 \%$, plastic limit $=21 \%$, PI $=12 \%$, specific gravity, $\mathrm{G}_{\mathrm{s}}=2.65$. The soil is classified as CL according USCS soil classification, and A-6 according to AASHTO soil classification. The soil consists of $55 \%$ silt, $16 \%$ sand, and $29 \%$ clay. The optimum moisture content according to the standard compaction test is $17.3 \%$ and a maximum wet density of $1.993 \mathrm{~g} / \mathrm{cm} 3$. Figures 2 shows the shear response of clay. The direct shear tests of the clay-clay interface were performed in a small direct shear device (SDSD). The size of sample was $100 \times 100 \times 25 \mathrm{~mm}^{3}$. Under shearing, there is a reduction in length and/or area of the sheared interface. Therefore, the shear stresses shown in Figure 2 are corrected. Based on figure 2, the friction angle, $\varphi=31.1^{\circ}$ and the cohesion, $c=8.34 \mathrm{kPa}$.

\section{Testing Procedures}

The concrete block was first placed and fixed at the bottom section of the shear box. The dried clay was mixed with $26 \%$ of the water and placed on top the shear box section. This process was done outside the large direct shear device. The first layer of the soil was compacted to $25 \mathrm{~mm}$ final thickness, 70 blows was applied to each soil layer using the modified proctor hammer. Three Thermocouples were placed at the center, corner, and one the far middle side of the clay sample. Second soil layer was added and compacted same as the first layer. At the end of the compaction, the wet density was $1.86 \mathrm{~g} / \mathrm{cm}^{3}$, moisture content was $26 \%$, and dry density was 1.49 $\mathrm{g} / \mathrm{cm}^{3}$. The initial degree of saturation (S) was $96.5 \%$, and the void ratio (e) was 0.89 . After preparing the clay specimen, a filter paper was saturated and placed on top of clay surface. Then, the porous stone was placed over the filter. The shear box was placed inside the water bath of the large direct shear device and left submerged in the circulated water for 24 hours under a normal stress of 3.45 $\mathrm{kPa}$ to ensure saturation condition is met and to prevent swelling. 


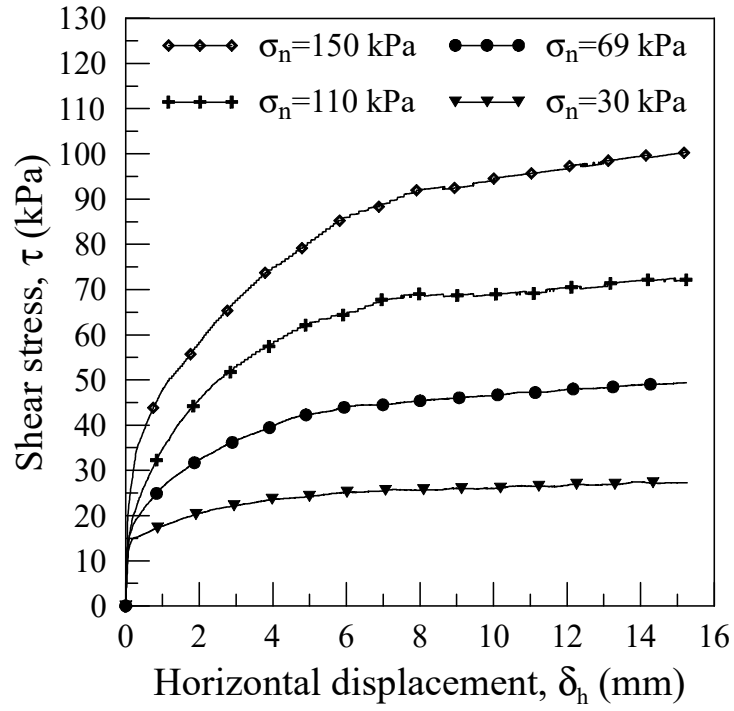

Fig. 2. Shear strength response of the lean clay under different normal stresses.

Eight tests were conducted using this soil. The soil was tested under four different normal stresses for both; with heating and without heating conditions. The four chosen different normal stresses $(30,69,110$, and 150 $\mathrm{kPa})$ were selected for shear testing. These stresses were chosen to depict the confining stress of four shallow depths on a pile. The normal stress was increased from the sitting load of $3.45 \mathrm{kPa}$ to the targeted normal stress. The clay specimens were left under consolidation until the primary consolidation was completed. The consolidation stage took around one day. For tests that are not subjected to thermal loading, shearing starts directly after the end of consolidation.

Thermal loading was applied immediately after consolidation for the tests that are subjected to a heatingcooling cycle. The system was covered by aluminium foil to reduce the amount of evaporated water as much as possible. The temperature of the system was monitored during heating via the four thermocouples. The target temperature was $70{ }^{\circ} \mathrm{C}$. In stage 1 (i.e. heating), the temperature was increased from the room temperature (usually from $20-23{ }^{\circ} \mathrm{C}$ ) to $70{ }^{\circ} \mathrm{C}$ in around $150-200$ minutes. After reaching the target temperature of $70^{\circ} \mathrm{C}$, the temperature was kept constant at $70^{\circ} \mathrm{C}$ in stage 2 . The duration of phase 2 was controlled by two conditions which need to be satisfied before starting phase 3 . These conditions are: 1 - The temperature of the system must reach a homogenous or steady state (i.e. all four thermocouples (three inside the clay specimen and one in the water bath) reached the target temperature $+2{ }^{\circ} \mathrm{C}$ and no further change occur). 2- No further soil volumetric strain was observed (i.e. ensuring a full dissipation of the induced excess pore water pressure).

When the above conditions were met, the heaters were shut down and the temperatures dropped to the room temperature again. During cooling stage, the heaters were shut down and the temperatures dropped to the room temperature again. The cooling stage took around 750 $\min$. Figures 3 and 4 show the average temperature of the four thermocouples and the corresponding volume change of the three phases under normal stresses of $30,69,110$, and $150 \mathrm{kPa}$.
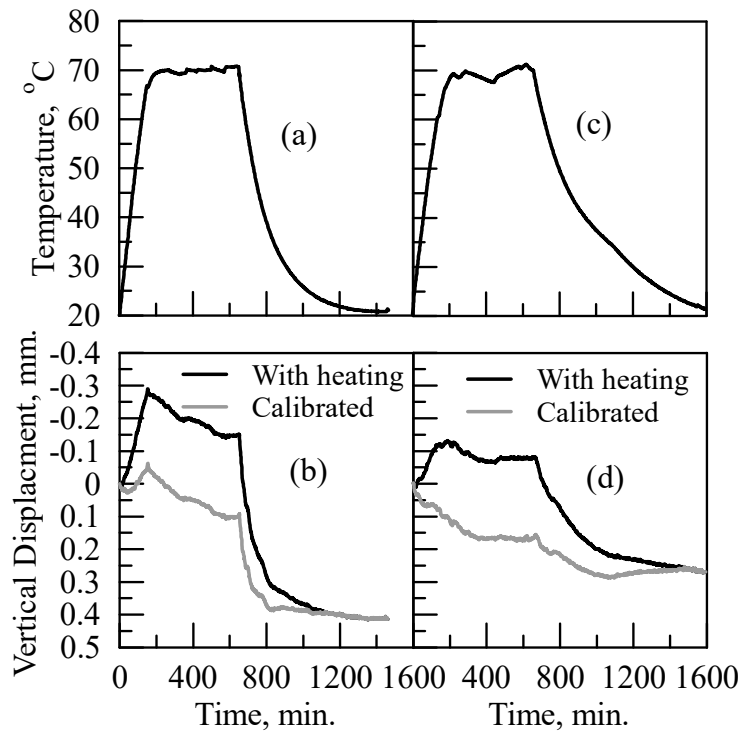

Fig. 3. Thermal loading, a- Average temperatures $(30 \mathrm{kPa})$, bVolume change under heating $(30 \mathrm{kPa})$, c- Average temperatures $(69 \mathrm{kPa})$, d- Volume change under heating (69 $\mathrm{kPa})$.
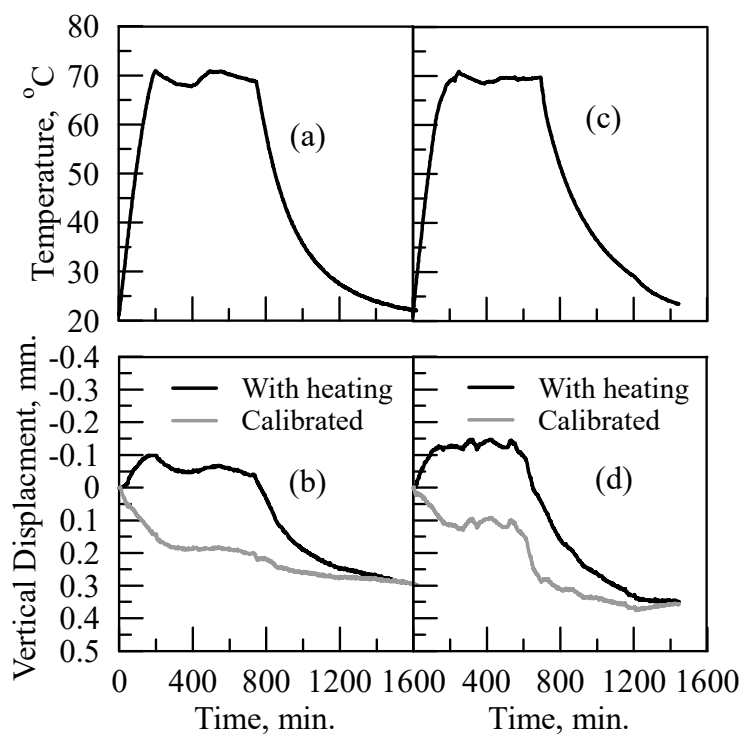

Fig. 4. Thermal loading, a- Average temperatures (16.0 psi), bVolume change under heating (16.0 psi), c- Average temperatures (21.8 psi), d- Volume change under heating (21.8 psi).

Condition 1 (i.e. temperature stabilization) was reached quickly within $40-60 \mathrm{~min}$ after the first thermocouple reached the target temperature $\left(70{ }^{\circ} \mathrm{C}\right)$. The actual readings of each thermocouple are not shown in this paper due to limited space. Also, condition 2 was satisfied after around $100 \mathrm{~min}$ after reaching the target temperature $\left(70{ }^{\circ} \mathrm{C}\right)$ for all tests except for $30 \mathrm{kPa}$ which needed $400 \mathrm{~min}$ as shown in figure $3-\mathrm{b}$. However, stage 2 for all tests was kept for 500-550 min. Figures 3-b, 3-d, 4- 
$\mathrm{b}$ and 4-d show the no further change in volume (i.e. vertical displacement) prior to cooling.

Also, under cooling in phase 3 , there is a volume change. Before starting shearing, no further volume change occurred. Furthermore, figures 3-b, 3-d, 4-b and 4-d show two vales of vertical displacement, with heating and calibrated values. These two values will be discussed furthermore in the next sections.

The last step of this test is shearing. Before shearing, a gap between the upper and lower boxes was created by removing the bolts that are connecting the shear boxes and creating a gap of around $2 \mathrm{~mm}$. Constant shearing rate condition was targeted during shearing. Since drained shearing condition is needed in this study, a very low shearing rate was selected to ensure a drained condition to allow the dissipation of excess pore water pressure. The lowest shear rate recorded in literature was adopted in this research, which is $0.005 \mathrm{~mm} / \mathrm{min}=0.0002^{\prime \prime} / \mathrm{min}$. The horizontal deformation at failure was assumed to be 1.5 $\mathrm{cm}$. It took $3000 \mathrm{~min}$ (around two days) to finish shearing for each test. Circulation of heated water was kept active during shearing phase to ensure full saturation condition.

\section{Calibration}

The volume change data during both heating and cooling needed calibration due to the sensitivity of the LVDT and thermal expansion of shear box, concrete block, and aluminium cap. This was achieved by performing four tests in the consolidation phase under the four different normal stresses of $30,69,110$, and $150 \mathrm{kPa}$ in which heating and cooling was included. In these tests the clay specimens were removed from the system (i.e. the concrete block in the lower shear box, filter paper and porous stone in the upper shear box). For these tests, the volume change was recorded along with the temperatures. The recorded volume change is due to the whole system without the clay specimen. Therefore, these volume changes were removed from the original test results according to the value of temperature and its corresponding volume change in the calibrated test. As a result, the final value of vertical displacement is the calibrated value for the clay specimen alone under heating and cooling. Figures 3-b, 3-d, 4-b and 4-d show the calibrated values and the uncalibrated (i.e. with heating) values.

\section{Test results and discussions}

Figure 5 presents the horizontal displacements versus the vertical displacements during shearing under the four different normal stresses of clay-concrete interface. It also shows the results for the tests that were subjected to one heating-cooling cycle and those without heating. The maximum values of vertical displacements for the tests that were subjected to a heating-cooling cycle ranged between $0.264 \mathrm{~mm}$ and $0.604 \mathrm{~mm}$ under the four normal stresses. Also, it ranged between $0.374 \mathrm{~mm}$ and $0.798 \mathrm{~mm}$ for the tests that were not subjected to a heating-cooling cycle. Figure 6 depicts the shear strength versus horizontal displacement under the four different normal stresses of the clay-concrete interface with and without one heating-cooling cycle. The maximum shear strength for the tests without heating-cooling cycle are is $13 \mathrm{kPa}$, $29.7 \mathrm{kPa}, 45.85 \mathrm{kPa}$, and $71.7 \mathrm{kPa}$ under $30,69,110$, and $150 \mathrm{kPa}$, respectively. Also, displacement at maximum stresses ranged between $4.5 \mathrm{~mm}$ to $5.6 \mathrm{~mm}$. The maximum shear strength for the tests with heating-cooling cycle are $16.8 \mathrm{kPa}, 36 \mathrm{kPa}, 54.2 \mathrm{kPa}$, and $80.7 \mathrm{kPa}$ under $30 \mathrm{kPa}, 69 \mathrm{kPa}, 110 \mathrm{kPa}, 150 \mathrm{kPa}$, respectively, with a range of displacements between $4.6 \mathrm{~mm}$ and $6 \mathrm{~mm}$. The peak and residual shear strengths of all tests on the shear strength-normal stress plane, adopting the Mohr-coulomb failure criteria, was plotted as shown in figures 7 and 8 , respectively. To provide a better fit for the data, the intercepts of the failure envelopes were fixed at zero following the work of Murphy and McCartney [15].

The sudden heating of the saturated clay will cause pore thermal water pressure generation, since the rate of heating is faster than the rate of the thermal pore water pressure dissipation [3, 14, 17]. Reduction in the volumetric strain was observed due to the dissipation of pore water pressure and physico- chemical structure interaction [7]. Following figures 3-d, 4-b, and 4-d, a volume reduction is observed until reaching the target temperature followed by fluctuating but tend to have a constant volume response during the constant high temperature. In contrast, in figure 3-b, under normal stress of $30 \mathrm{kPa}$, a slight volume expansion is observed at the beginning of heating before following the same trend that shown in figures 3-d, 4-b, and 4-d. Also, under $30 \mathrm{kPa}$, the volumetric deformation took more time to stabilize compared to the behaviour of other tests. An excessive contraction is observed during the cooling phase under all normal stresses. This behaviour is well known for the normally consolidated soil $[3,14,17]$. The volumetric strain due to heating-cooling cycle was $0.8 \%, 0.5 \%, 0.6 \%$, and $0.7 \%$ under $30 \mathrm{kPa}, 69 \mathrm{kPa}, 110 \mathrm{kPa}$, and $150 \mathrm{kPa}$, respectively.

The volumetric response with the horizontal displacement of the clay-concrete interface without heating (Figure 5) shows that the vertical displacement under shearing increases with increasing the normal stress. The rate of vertical displacement is much higher within the first $5 \mathrm{~mm}$ of horizontal displacement as compared to the next $10 \mathrm{~mm}$. This observation is almost the same under all normal stresses, but at higher rate with increasing normal stress. In the same figure, the results of the tests that were subjected to one heating-cooling cycle almost follow the same trend to those that were not subjected to heating cycle. The vertical displacement increases with increasing the normal stress. The rate of vertical displacement with horizontal displacement in the first $5 \mathrm{~mm}$ is much higher than the following $10 \mathrm{~mm}$. However, when comparing the shear tests that were subjected to heating cycle with those without heating, under the same normal stress, higher vertical displacement was observed for the tests that were not subjected to heating cycle under all normal stresses. After heating-cooling cycle, the maximum vertical displacement was reduced by $30.0 \%, 24.4 \%, 11.3 \%$, and $24.2 \%$ under $30 \mathrm{kPa}, 69 \mathrm{kPa}, 110 \mathrm{kPa}$, and $150 \mathrm{kPa}$, respectively. The reason behind this volumetric 
observation under shearing is because the material was further consolidated due to thermal loading which reduced the initial void ratio [9].

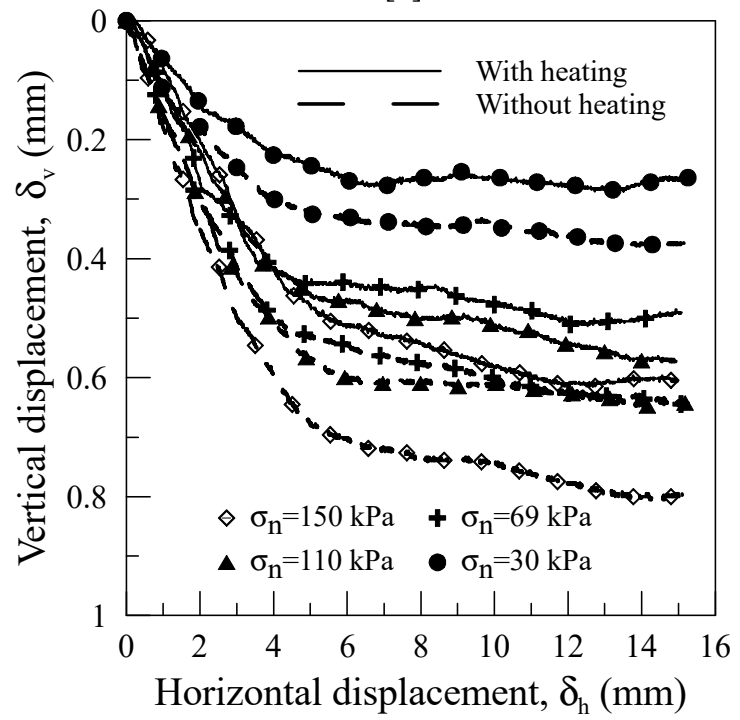

Fig. 5. Volumetric response under shearing for the clay-concrete interface.

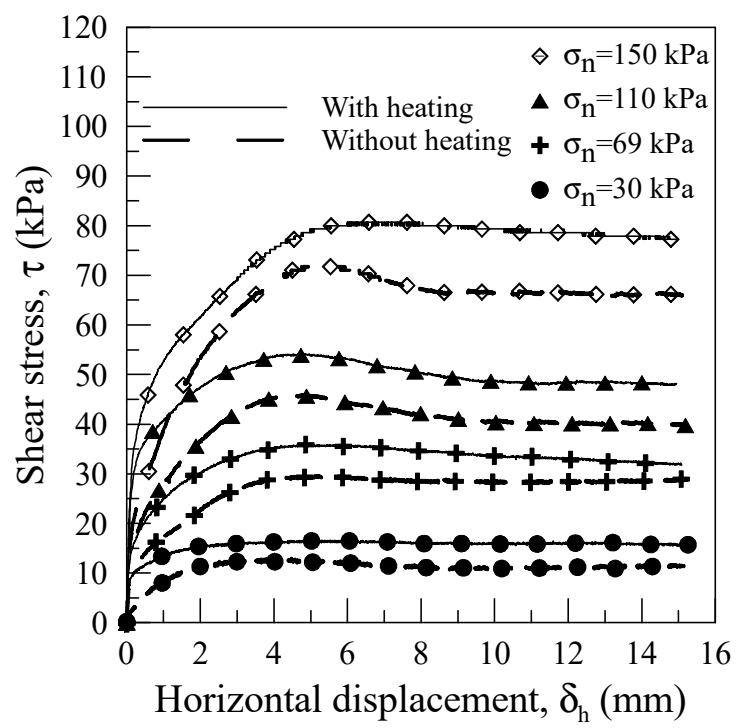

Fig. 6. Clay-concrete interface shear strength.

The results of shear strength versus horizontal displacement curves for the clay-concrete interface with and without heating-cooling cycle (Figure 6) clearly demonstrate that, in all cases, the interface shear strength of specimens subjected to one heating-cooling cycle is higher than those without heating. This observation shows that the increase in peak shear strength is $29.3 \%, 21.1 \%$, $18.2 \%$, and $12.5 \%$ under $30 \mathrm{kPa}, 69 \mathrm{kPa}, 110 \mathrm{kPa}$, and $150 \mathrm{kPa}$, respectively. Also, the increase in residual shear strengths are $37.3 \%, 11.0 \%, 21.35 \%$, and $17.15 \%$ under $30 \mathrm{kPa}, 69 \mathrm{kPa}, 110 \mathrm{kPa}$, and $150 \mathrm{kPa}$, respectively. At the peak shear strength, the interface friction angle, $\delta$, increased by $13.6 \%$, from $24.3^{\circ}$ to $27.6^{\circ}$ (Figure 7 ); while $\delta$ increased by $15.6 \%$, from $22.4^{\circ}$ to $25.9^{\circ}$, at the residual strength (Figure 8). According to Di Donna [9], Di Donna and Laloui [10], Yavari et al. [19], and Yazdani et al. [20], the reason behind the increase in shear strength after heating-cooling cycle is the thermal consolidation or thermal solidification. The same explanation is believed to be the reason behind the increase in shear strengths and shear strength parameters in this study.

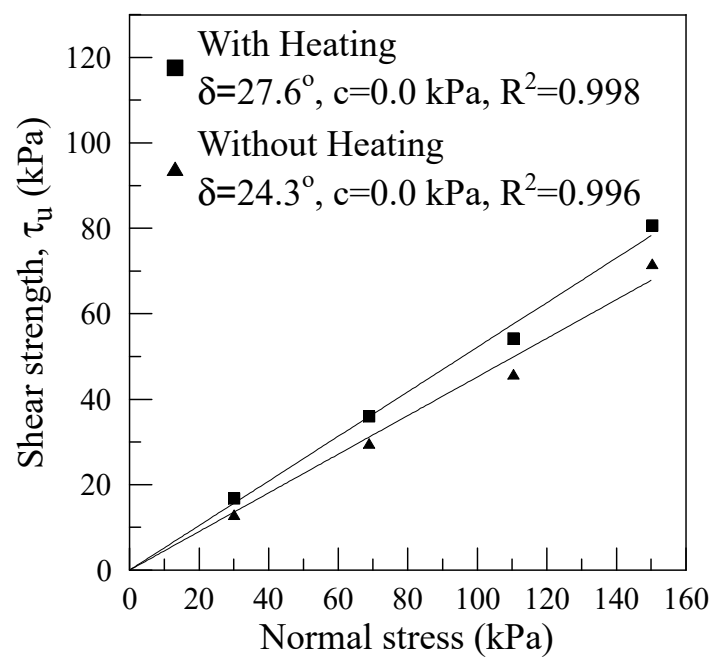

Fig. 7. Clay-concrete peak shear strength parameters.

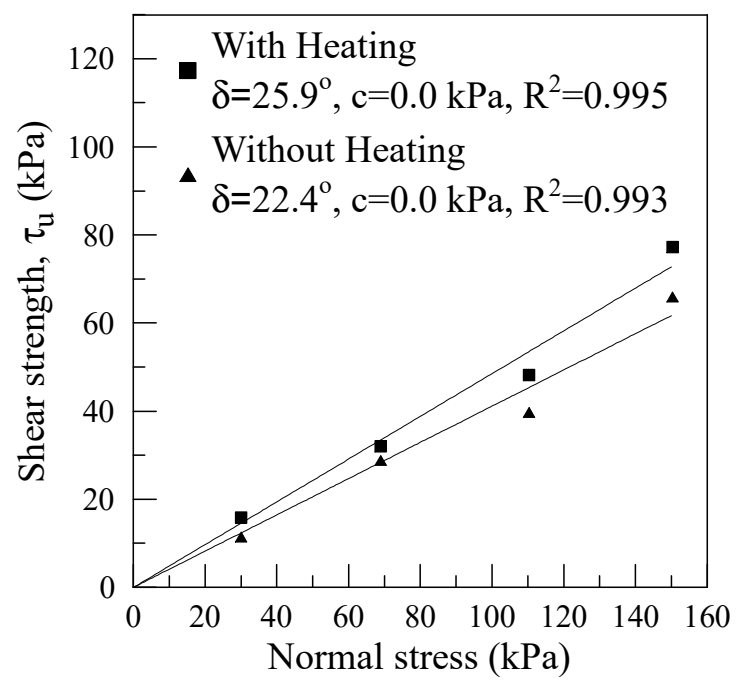

Fig. 8. Clay-concrete residual shear strength parameters.

\section{Summary and Conclusions}

A large direct shear test device (dimensions $=300 \mathrm{~mm} \times$ $300 \mathrm{~mm} \times 200 \mathrm{~mm}$ ) was modified and used in this study to evaluate the clay-concrete interface shear strength with and without one heating-cooling cycle for potential application to increase the pile capacity through heating. Also, to study the potential geothermal pile applications All clay specimens were prepared under the same conditions with respect to unit weight, moisture content, consolidation and heating-cooling cycle. The clay 
specimens were first consolidated under different normal stresses of $30,69,110$, and $150 \mathrm{kPa}$, and then subjected to shearing with and without heating. For specimens subjected to heating, the temperature was increased to 70 ${ }^{\circ} \mathrm{C}$ during the heating stage, which was followed by cooling to the room temperature of about $20{ }^{\circ} \mathrm{C}$. The test results showed that heating has significant improvement in shear strength parameters of clay-concrete interface. Both the peak and residual shear strength parameters were increased for specimens subjected to one heating-cooling cycle.

The authors would like to acknowledge the Louisiana Transportation Research Center (LTRC) for supporting this research project.

\section{References}

1. Abuel-Naga, H. M., Bergado, D. T., \& Bouazza, A. (2007). Thermally induced volume change and excess pore water pressure of soft Bangkok clay. Engineering Geology, 89(1-2), 144-154.

2. Abuel-Naga, H. M., Bergado, D. T., \& Lim, B. F. (2007). Effect of temperature on shear strength and yielding behavior of soft Bangkok clay. Soils and Foundations, 47(3), 423-436.

3. Abuel-Naga, H. M., Bergado, D. T., Ramana, G. V., Grino, L., Rujivipat, P., \& Thet, Y. (2006). Experimental evaluation of engineering behavior of soft Bangkok clay under elevated temperature. Journal of geotechnical and geoenvironmental engineering, 132(7), 902-910.

4. Abuel-Naga, H., Bergado, D. T., Bouazza, A. and Ramana, G. (2007). Volume change behaviour of saturated clays under drained heating conditions: experimental and constitutive modelling. Canadian Geotechnical Journal, 44, 942-956.

5. Baldi, G., Hueckel, T., \& Pellegrini, R. (1988). Thermal volume changes of the mineral-water system in low-porosity clay soils. Canadian geotechnical journal, 25(4), 807-825.

6. Burghignoli, A., Desideri, A., \& Miliziano, S. (2000). A laboratory study on the thermomechanical behaviour of clayey soils. Canadian Geotechnical Journal, 37(4), 764-780.

7. Campanella, R. G., \& Mitchell, J. K. (1968). Influence of temperature variations on soil behavior. Journal of Soil Mechanics \& Foundations Div.

8. Coccia, C. J. R., \& McCartney, J. S. (2012). A thermo-hydro-mechanical true triaxial cell for evaluation of the impact of anisotropy on thermally induced volume changes in soils. Geotechnical Testing Journal, 35(2), 227-237.

9. Di Donna, A. 2014. Thermo-mechanical aspects of energy piles. Ph.D. thesis, Swiss Federal Institute of Technology in Lausanne (EPFL), Lausanne, Switzerland.

10. Di Donna, A., and Laloui, L. 2013. Advancements in the geotechnical design of energy piles. In Proceedings of the International Workshop on Geomechanics and Energy - The Ground as Energy
Source and Storage, Lausanne, Switzerland. Google Scholar

11. Elzeiny, R., Suleiman, M. T., Qamar, M. A. A., Xiao, S., \& Al-Khawaja, M. Axial Pull-Out Response of a Small-Scale Concrete Pile Subjected to Cyclic Thermal Loading in Sand. In IFCEE 2018 (pp. 706714).

12. Ghaaowd, I., McCartney, J., Huang, X., Saboya, F., \& Tibana, S. (2018). Issues with centrifuge modelling of energy piles in soft clays. In Physical Modelling in Geotechnics, Volume 2 (pp. 13651370). CRC Press.

13. Hueckel, T., \& Baldi, G. (1990). Thermoplasticity of saturated clays: experimental constitutive study. Journal of geotechnical engineering, 116(12), 17781796.

14. Laloui, L. (2001). Thermo-mechanical behaviour of soils. Environmental geomechanics. EPFL Press, Lausanne, 809-843.

15. Murphy, K. D., \& McCartney, J. S. (2014). Thermal borehole shear device. Geotechnical Testing Journal, 37(6), 1040-1055.

16. Towhata, I., Kuntiwattanakul, P., \& Kobayashi, H. (1993). A preliminary study on heating of clays to examine possible effects of temperature on soilmechanical properties. Soils and Foundations, 33(4), 184-190.

17. Uchaipichat, A., \& Khalili, N. (2009). Experimental investigation of thermo-hydro-mechanical behaviour of an unsaturated silt. Géotechnique, 59(4), 339-353.

18. Xiao, S., Suleiman, M. T., \& McCartney, J. S. (2014). Shear behavior of silty soil and soil-structure interface under temperature effects. In Geo-Congress 2014: Geo-characterization and Modeling for Sustainability (pp. 4105-4114).

19. Yavari, N., Tang, A. M., Pereira, J. M., \& Hassen, G. (2016). Effect of temperature on the shear strength of soils and the soil-structure interface. Canadian Geotechnical Journal, 53(7), 1186-1194.

20. Yazdani, S., Helwany, S., \& Olgun, G. (2019). Experimental Evaluation of Shear Strength of Kaolin Clay under Cyclic and Noncyclic Thermal Loading. Geotechnical Testing Journal, 42(6), 1518-1548. 